УдК 686.12.056

\title{
ВПЛИВ ТЕХНОЛОГІЧНИХ ПРОЦЕСІВ РІЗАННЯ АРКУШЕВИХ МАТЕРІАЛІВ НА ЯКІСНІ ХАРАКТЕРИСТИКИ ПРОДУКЦІї
}

\author{
(ㄱ А. І. Іванко, К.Т.н, доцент, К. О. Чепурна, к.Т.н, доцент, \\ К. О. Махинич, магістрантка, НТУУ «КПІ», Київ, Україна
В статье проведен анализ технологических процессов резки листовых материалов и их влияние на качественные показатели полиграфической продукции.

In the article the analysis of technological processes of cutting sheet materials and their influence on the high-quality indexes of printing products.

\section{Постановка проблеми}

Визначальним фактором конкурентоспроможності поліграфічної продукції $€$ підвищення рівня зовнішнього оформлення та удосконалення технологічних процесів ї̈ виготовлення. Особлива увага приділяється післядрукарським процесам, тобто завершальній стадії підготовки видання.

Найбільш складною операцією фінішної обробки $\epsilon$ підрізування та розрізування скомплектованих у стос аркушів. Від правильного вибору обладнання та технологічних режимів різання залежатиме якість площини зрізу.

\section{Аналіз попередніх досліджень}

Проведені експериментальні дослідження способів обрізування скомплектованих аркушів у книжкові блоки свідчать про передумови і можливості одночасного збільшення продуктивності та покращення якості поверхні зрізу. Слід дотримуватись поставлених рекомендацій щодо технологічних вимог: відсутність перекосів по довжині і ширині аркушевого матеріалу; відсутність смуг, хвилястостей та заглибин площини зрізу; відсутність злипання кромок аркушів; відсутність деформацій корінця від транспортувальної системи або балки притиску (триножові різальні машини, одноножові паперорізальні машини); дорізування останніх від ножів аркушів у блоці [1-5].

Геометрична форма напівфабрикату після обрізування повинна мати граничний допуск по ширині і висоті у межах $\pm 1,5$ мм, на перекошування \pm 2 мм. Граничні відхилення від розміру не можуть перевищувати \pm 1 мм, а перекошування геометричної форми не більше 0,1 \% від загальної довжини при підрізуванні блоків на паперорізальних машинах [1-5].

Постійне впровадження широкого асортименту нового за фізико-механічними характеристиками паперу зумовлює ство- 
рення нових технологій його обробки.

\section{Мета роботи}

В основі досліджень поставлена мета проаналізувати ряд факторів, що впливають на якісні характеристики обрізування аркушевих матеріалів у різальних секціях спеціалізованого устаткування. Шляхи прогнозованого підвищення якості та продуктивності роботи різальних секцій.

\section{Результати проведених досліджень}

Технологічний процес різання характеризується заданою послідовністю операцій: підготовка аркушевого матеріалу та його вирівнювання (базування), фіксування балкою притиску або засобами транспортування та обрізування. Від правильного виконання даної послідовності залежить точність та якість обрізування стосу аркушів або привертки книжкових блоків.

Найбільшими виробниками різальних машин є такі фірми як: Polar, Schneider-Senator, Wohlenberg, Ideal, Eurocutter, Perfecta, Josting (Німеччина), Adast Blansko (Чехословаччина), EBA, Shenweida (Китай), Nagai, Horizon (Японія), Challenge (США), S.E.M. (Франція) та інші.

На сьогодні застосовуються різні конструкції різальних машин. Марзанний та безмарзанний спосіб обрізування використовується залежно від поставлених вимог до площини зрізу. У випадку одноножових паперорізальних машин (ОРМ), з використанням марзану забезпе- чується відмінна якість площини зрізу. Однак ОРМ переважно циклові машини 3 малою швидкістю роботи. В більшості випадків різальні секції, в яких використовується контрніж, $€$ безупинного типу, мають відносно високу продуктивність роботи та меншу якість зрізу.

Сприяють продуктивності та якості процесу розрізування аркушезіштовхувальні автомати (Perfecta, Polar, Wohlenberg), що входять в систему ОРМ, і на сьогоднішній день передбачають роботу з крейдованим папером та високою гладкістю поверхні.

На якісні характеристики процесу зіштовхування паперу впливає: розпушування аркушів; створення між аркушами повітряних прошарків; вирівнювання торцевих країв аркушів до поверхні подавача.

Ускладнює процес зіштовхування: збільшення формату аркушів; гладкість паперу; недостатня вологість аркушів, яка спричиняє виникнення статичної електрики у злиплих аркушів за рахунок чого унеможливлюється утворення повітряних прошарків; підвищена вологість аркушів, що збільшує тертя між аркушами; щільність паперу (проблемне зштовхування стосовно тонких аркушів).

Щодо способів обрізування книжково-журнальних блоків (КЖБ) з трьох боків у триножових різальних машинах (ТРМ), то вони відрізняються принципом роботи та побудовою:

- одноножові машини 3 поворотним столом;

- однопозиційні триножові машини; 
- двопозиційні триножові машини;

- машини для поштучного обрізування книжково-журнальних блоків.

Висота привертки є вузьким місцем ТРМ. Так збільшення її висоти призводить до значних відхилень геометричних розмірів у верхньому та нижньому блоці.

Для ТРМ, де встановлено один ніж, характерні відносно малі габарити та відносно спрощений технологічний процес різання. Обрізування блоків 3 трьох боків відбувається привертками впродовж трьох кінематичних циклів. Після кожного циклу різання ножа стіл автоматично повертається на кут $90^{\circ}$ i цикл руху ножа повторюється. Для обрізування КЖБ з трьох боків характерна технологічна зупинка напівфабрикатів. Зупинка напівфабрикату та значні інерційні навантаження у механізмах не дозволяють перевищити технічну швидкість машин більше від 100 ц/хв.

Відомі компанії-виробники TPM Wohlenberg, Perfecta (Німеччина), Horizon (Японія), Purlux, Clarity (Китай) постійно ведуть роботу над удосконаленням щодо збільшення продуктивності та покращення якості продукції.

Поштучне обрізування книжкового або журнального блока виконується в автоматизованих потокових лініях під час зупинки напівфабрикату, або у вкладально-швейно-різальних агрегатах (ВШРА). В таких машинах використовуються самонаклади, завантажувальні та вивідні транспортери, штовхачі, щупи тощо.
Кожна окрема різальна секція може бути оснащена трьома однаковими по конструкції різальними пристроями. Вони послідовно обрізують блоки з трьох боків ножами, які рухаються В горизонтальній площині. Книжковий блок фіксується затискачами ланки конвеєра і переміщується в секцію обрізування. Притискач переміщується до нерухомого ножа, при цьому блок додатково закріплюється безпосередньо в зоні різання. Затискачі перед кожною різальною секцією повертаються разом з блоком на кут 90․ Таким чином відбувається почергове обрізування хвоста, головки та передка блока.

В різальних секціях ВШРА автомат може обрізувати брошури у двох позиціях (спочатку першим ножем обрізується передок брошури, а потім боковими ножами її головка та хвіст). Для розрізування зошитів-двійників між боковими ножами встановлюється додатковий ніж. Обрізування здійснюється без використання марзанів. Їх функцію виконують контрножі.

Секції для обрізування блоків з трьох боків використовуються також у складі машин незшивного клейового скріплення. Відомі виробники Muller-Martini (Швейцарія) та Heidelberg Finishing (Німеччина).

Визначальним фактором впливу на якісні показники площини зрізу $є$ сумарне зусилля різання, та сила затиску паперу залежно від його фізикомеханічних характеристик. Відповідно під дією сили тиску притиску виникає місцеве стис- 
нення аркушів, а ніж рухаючись слідом за притискачем створює тиск в площині різання. На ніж будуть діяти ряд сил. Так, важливими за значенням $€$ опір стосу та тиск на тильну площину ножа. Скошеною гранню ніж діє на кромки попередньо відрізаних аркушів. Відповідно виникає сила опору - лобова сила та сили тертя. Виникає технологічне зусилля, що спричиняє додатковий опір переміщенню ножа та сила внаслідок тертя країв аркушів по скошеній частині ножа. Такі зусилля, що діють на ніж під час різання визначально впливають на технологічні та конструктивні показники різального обладнання.

Максимальне зусилля різання $\mathrm{F}_{\text {max }} \in$ основним параметром процесу обрізування, що впливає на якісні показники. Тобто зусилля, що створюється шаблевидним рухом ножа для розрізування аркушів $\mathrm{F}_{\max }=$ = kpL, де $\mathrm{k}$ - коефіцієнт запасу; $\mathrm{p}$ - погонне зусилля різання, що залежить від фізико-механічних характеристик паперу та кута загострення ножа; L ширина привертки блоків.

Основними факторами, що визначають зусилля різання є: геометричні розміри книжкових блоків; кут загострення ножа, траєкторія його руху та швидкість; сила притиску блоків; товщина аркушів та їх вологість.

Одним 3 найбільш ефективних шляхів зменшення технологічних зусиль різання, підвищення стійкості ножа та покращення якості зрізу є надання ножу ОРМ вібраційних коливань.
Спосіб розрізування аркушів паперу на ОРМ з вібруючим ножем характерний тим, що ножу, крім його основного руху, надається вібраційний з вибраною амплітудою та частотою. Аркуші розрізаються ножем, що вертикально опускається 3 наданими йому коливаннями. Коливання забезпечуються віброзбудником.

Основними технологічними параметрами, що впливають на якісні характеристики процесу вібраційного різання аркушів $\epsilon$ напрямок коливань та вид руху ножа. Таким чином вони і забезпечують мінімальні сили різання та зменшують сили притиску. Технологічний процес вібраційного різання аркушів паперу суттєво змінює кінематичні параметри, особливо трансформовані дійсні швидкості та кути різання. Така зміна вагомо впливає не тільки на якість та точність площини зрізу, але і на величину та характер енергосилових показників. Можна зробити висновок, що вібрації впливають на кінематику процесу обрізування періодично змінюючи величини і напрямок вектора швидкості різання. Це призводить до періодичної зміни кінематичних кутів різального інструмента.

Найбільших значень при різанні набуває вертикальна складова сили різання. У більшості випадків, дана складова буде залежною від кута загострення ножа та його траєкторії руху. Горизонтальна і лобова складові визначається у відсотковому відношенні до вертикальної сили різання.

Якість зрізу при технологічному процесі вібраційного 
різання буде відмінною при застосуванні пневмомарзана для дорізування останніх від ножа аркушів. Дорізування нижніх аркушів на пневмомарзані, порівняно з традиційними ОРМ, дозволяє суттєво підвищити період роботи різального інструмента та зменшити енергосилові параметри процесу. Якщо порівняти існуючі способи віброрізання при рівних умовах, наприклад, коливання з частотою $\mathrm{f}=50$ Гц та кут загострення ножа $\alpha_{3}=20^{\circ}$, то найменші трансформовані дійсні кути різання досягаються при наданню ножу поперечних коливань. Відповідно для досягнення найменших сил різання доцільно використовувати поперечні вібрації різального інструмента.

Значний вплив на якість різання має геометрична форма та кут загострення ножа, яку слід підбирати відповідно до матеріалу, що розрізається. Для часткового зменшення зусиль різання здійснюють загострення ножа ОРМ під «подвійним» кутом з різницею у $3 . .5^{\circ}$ та фаскою 2...4 мм. Для запобігання інтенсивного зношування ножа застосовують дорогі марки сталей. Так різноманітність паперів за фізико-механічними характеристиками, обладнання, способів різання вимагає добору i використання різноманітних класів ножів. Ножі використовують, як правило з інструментальних сталей. За допомогою сучасних технологій термічної обробки отримують хорошу мікроструктуру сталі із обґрунтованим співвідношенням між твердістю і стійкістю. Найбільш поширені ножі з інструментальних сталей Durapid, високолегованих хромованих сталей Chromalit - 12 \% Chrom., швидкоріжучих сталей та зносостійких сталей Duritan - HSS $18 \%$ W., Incomet - TCT, Incomet - F та ін.

Постійний контроль за якістю вимагає періодичної заміни марзану і ножа. Це призводить до технологічних зупинок в роботі. Власне процес розрізання стосу займає $6 . .7 \%$ робочого часу. Збільшення продуктивності різального обладнання можливе у разі застосування для додаткових операцій автоматизованих пристроїв зіштовхування, переміщення та вирівнювання стосу, тощо.

Також для обрізування книжкових блоків застосовується безупинний спосіб з використанням багатолезового різального інструменту (БРІ). Технологічний процес різання реалізується наступним чином: блок подається в зону різання транспортером; губки транспортера одночасно здійснюють фіксацію блока і переміщення його в зону різання; різальні інструменти основний та допоміжний встановлені на нерухомих основах транспортера. У БРІ передбачено регулювання його положення в площині різання. В зоні різання крайки лез БРІ почергово врізаються в блок. Кожне окреме лезо завдяки своїй конструкції розрізає частину блока на задану глибину $\mathrm{h}$ [6].

Період експлуатації БРІ та, як наслідок, якість площини зрізу корінця можна підвищити використавши конструкцію, що скла- 
дається з окремих дисків з різальними кромками. Диски монтуються в ножотримачі 3 можливістю зміни їх положення. Це дозволяє при затупленні різальних кромок ножа відновити його працездатність шляхом повороту дисків на визначений кут. Таким чином, збільшується період експлуатації до перезагострення або заміни ножа. Крім того, розташування лез по коловій траєкторії забезпечує якісне зрізування корінців брошурних блоків.

Застосування БРІ має певне обмеження, щодо товщини КЖБ, яка не повинна перевищувати 25-30 мм. Для обрізування блоків більшої товщини пропонуються конструкції V-подібних різальних інструментів: лінійних (ЛРІ) та фасонних (ФРІ). Якщо у лінійних PI вершини лез розміщені на прямих, то у фасонних на кривих. V-подібний ФPI передбачає можливість програмованої зміни глибини різання h окремими лезами.

Обрізування книжкових блоків дисковим ножем значно спрощує конструкцію різальної секції, дає можливість здійснити обрізування під час переміщення напівфабрикату, і як наслідок, підвищити якісні показники. Дисковий різальний інструмент порівняно з плоским має ряд переваг. Основною перевагою вважається зносостійкість. При однакових умовах експлуатації дискові ножі будуть більш стійкими до спрацювання. Це пояснюється довжиною ділянки леза різального інструмента, що приймає участь у процесі обрізування корінця блока.
Для суттєвого зменшення зусилля різання, порівняно із традиційним способом, застосовують дискретно-дотичний спосіб обрізування КЖБ. Так, споживана потужність приводу ножа при використанні оптимальних наборів параметрів різання не перевищує 400 Вт. Секція обрізування КЖБ може використовуватись у складі потокової лінії «Kolbus KM-640» [7].

Відомо, що процес різання супроводжується випереджаючою тріщиною. Тобто, розділення кожного окремого аркуша починається безпосереднім руйнуванням його верхніх волокон, а закінчується утворенням випереджаючої тріщини, що розповсюджується на наступну частину аркуша.

Довжина випереджаючої тріщини залежить від двох технологічних параметрів: по-перше, від кута, на який повинна повернутися частина аркушів, що відрізається; по-друге, від кривизни аркушів, що відрізаються. Чим більший кут, на який повинна повернутися частина аркушів, що відрізається, і чим менша кривизна частини аркушів, що відрізається, тим більша довжина випереджаючої тріщини.

Довжина випереджаючої тріщини, залежно від виду паперу, залежить від кута загострення ножа, діаметра ножа, відстані від краю ножа до площини січення та ширини смужки, що зрізується. Таким чином якість площини зрізу буде визначатись названими параметрами.

На основі проведеного аналізу визначено основні дефекти продукції та причини їх виникнення, які наведено на рис. 1. 


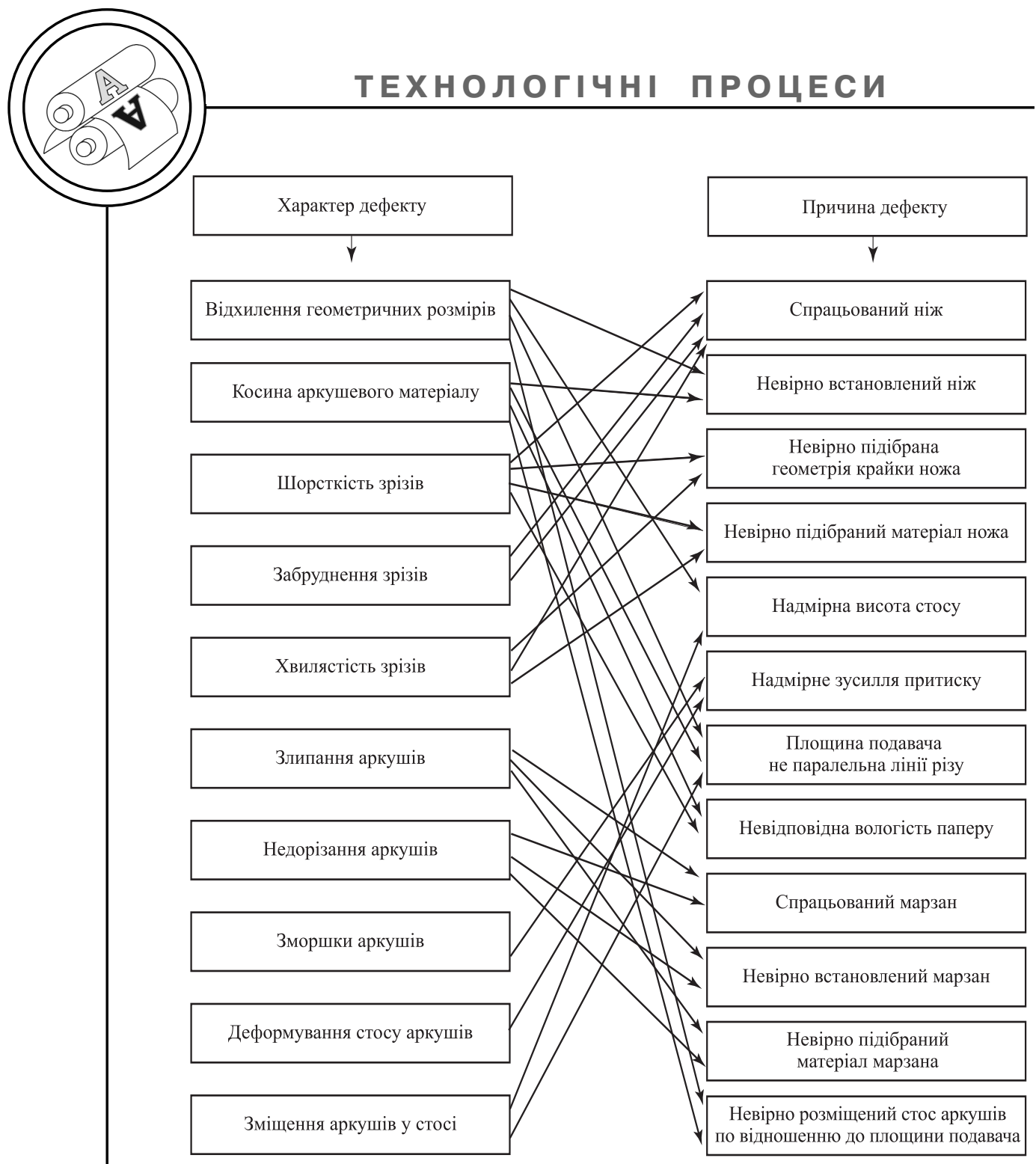

Рис. 1. Дефекти продукції, які виникають в процесі різання

Для визначення вагомості технологічних параметрів виникнення дефектів в процесі різання продукції застосовано метод розстановки пріоритетів незалежними експертами [8-9]. Порівняння параметрів проводилося за методикою евристичної стратегії [9-10]: при $X=Y-$ за 1; $X<Y-$ за 1,$5 ; X>Y-$ за 0,5 . Статистичну обробку проводили за методикою [11]. Було залучено провідних спеціалістів галузі, виробничників та викладачів. Всього було опрацьовано 45 матриць.

Головні параметри впливу на якісні показники продукції в процесі різання виділено у шість узагальнених груп: устаткування, технологія, матеріали, персонал, засоби вимірювання, навколишнє середовище. Цей перелік не викликає сумнівів і додаткових обґрунтувань, адже саме ці чинники $є$ умовою здійснення будь-якого технологічного процесу [12-13]. 
Узагальнена матриця експертних оцінок

\begin{tabular}{|c|c|c|c|c|c|c|c|c|}
\hline$X$ & 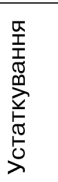 & 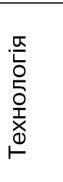 & 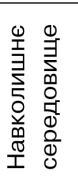 & 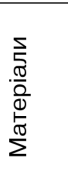 & 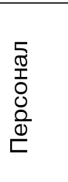 & 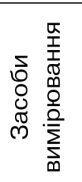 & 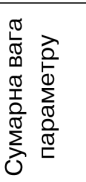 & $a, \%$ \\
\hline Устаткування & 45,0 & 67,5 & 67,5 & 67,5 & 45,0 & 67,5 & 360 & 23 \\
\hline Технологія & 22,5 & 45,0 & 67,5 & 67,5 & 45,0 & 67,5 & 315 & 20,0 \\
\hline $\begin{array}{l}\text { Навколишне } \\
\text { середовище }\end{array}$ & 22,5 & 22,5 & 45,0 & 22,5 & 22,5 & 45,0 & 180 & 11,5 \\
\hline Матеріали & 22,5 & 45,0 & 67,5 & 45,0 & 45,0 & 67,5 & 292,5 & 18,5 \\
\hline Персонал & 22,5 & 22,5 & 67,5 & 22,5 & 45,0 & 45,0 & 225 & 14,2 \\
\hline $\begin{array}{l}\text { Засоби } \\
\text { вимірювання }\end{array}$ & 22,5 & 22,5 & 45,0 & 22,5 & 45,0 & 45,0 & 202,5 & 12,8 \\
\hline & & & & & & & & 100,0 \\
\hline
\end{tabular}

На основі аналізу матриць експертних оцінок (див. табл.) було визначено вагомість параметрів виникнення дефектної продукції і побудовано діаграму Парето (рис. 2).

Як видно з рис. 2, близько $76 \%$ виникнення дефектної продукції пов'язані з порушенням роботи устаткування $(22,9 \%)$, недотриманням тех-

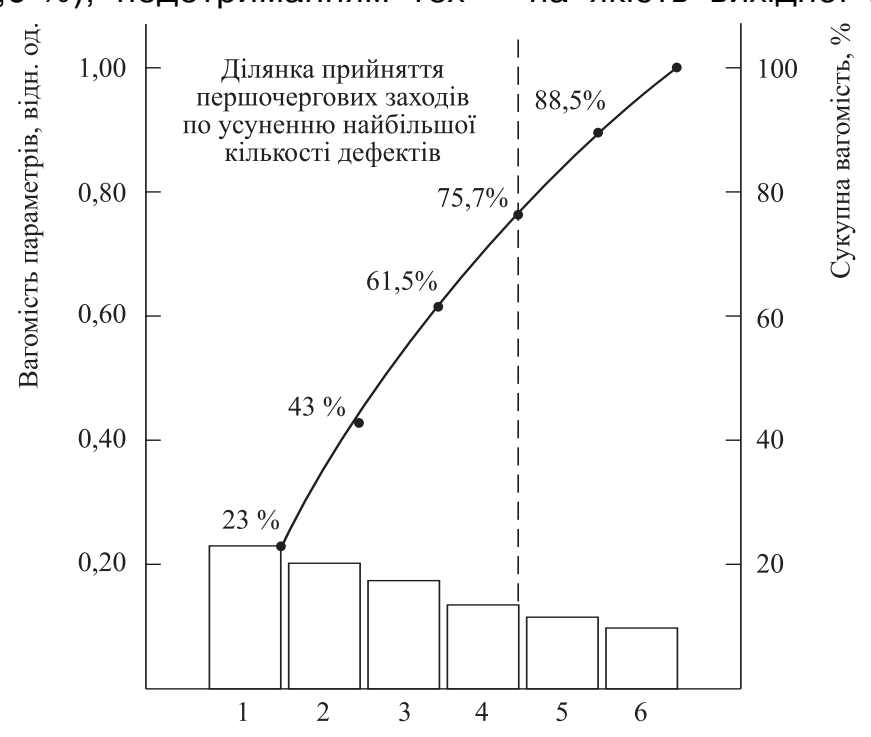

Рис. 2. Діаграма Парето для визначення ваги параметрів, які викликають дефекти продукції в процесі різання: 1 - устаткування, 2 - технологія, 3 - матеріали, 4 - персонал, 5 - засоби вимірювання, 6 - навколишнє середовище нології (20\%), невідповідними матеріалами (18,6\%), персоналом (14,3\%), менш вагомими $\epsilon$ засоби вимірювання (12,8\%) і навколишнє середовище $(11,4 \%)$, які було вирішено об'єднати у групу «інші», що мають вагу 24,2 \%.

Для аналізу та розуміння впливу зазначених параметрів на якість вихідної продукції в 
процесі різання розроблено причинно-наслідкову діаграму Ісікави (рис. 3) [14-16]. Усунення проблем, які пов'язані 3 порушенням технології та використанням невідповідних матеріалів (див. рис. 1, 2) полягає: по-перше, у суворому дотриманні вимог нормативних та робочих документів; по-друге, проведенні ряду досліджень для визначення оптимальних режимів для кожного виду матеріалу; по-третє, постійний вхідний контроль матеріалів (напівфабрикатів) [8, 14-16]. Вирішення проблем, пов'язаних з роботою персоналу, доречно здійснювати соціально-економічними заходами.

Найбільший вплив на виникнення невідповідної продукції має устаткування, а саме технічні та технологічні показники (див. рис. 2.1-2.3). Характеристики (властивості) та конструкційні особливості ножа, марзана, балки притиску $\epsilon$ найбільш визначальними чинниками якості продукції, яка контролюється за точністю геометричних розмірів, косиною та зовнішнім видом обрізів.

Отже, передумовою отримання продукції прогнозованої якості $\epsilon$ дотримання технологічних режимів процесу різання, використання відповідних матеріалів, обґрунтований вибір конструкції різальної машини та постійний контроль за станом устаткування.

\section{Висновки}

Проведений огляд способів обрізування аркушевих матеріалів дозволив встановити ряд факторів, які визначально впливають на якісні показники фінішної обробки поліграфічної продукції.

Розглянуті технологічні процеси обрізування дають можливість проаналізувати вплив їх силових параметрів на якість площини зрізу.

Безупинні способи обрізування та пристрої для їх реалізації над традиційними (вистійними) способами мають ряд переваг: збільшення продуктивності; зменшення часу на переналагодження устаткування; економія енергозатрат; зменшення металоємності і габаритів та ін. Немалу роль, щодо зносостійкості різальних інструментів, в даному устаткуванні, відіграє відсутність марзанів. Однак в переважній більшості якість площини зрізу залишається кращою у традиційних циклових машинах вистійного типу.

Визначено основні параметри впливу на якість напівфабрикатів в процесі різання та встановлено їх вагу.

1. Шостачук Ю. О. Техніка і технологія сучасного поліграфічного виробництва : навч. посіб. / Ю. О. Шостачук. - К. : НТУУ «КПІ», 2009. 244 с. 2. Хведчин Ю. И. Резальные машины и комплексы POLAR : учебн. пособ. / Ю. И. Хведчин, Ю. А. Шостачук, М. Овчар. - К. : ПКП «СТ-Друк», 2004. - 204 с. 3. Хведчин Ю. Й. Брошурувально-палітурне устаткування. Ч. 1. Брошурувальне устаткування. Підручник / Ю. Й. Хведчин. - Львів : ТеРус, 1999. - 336 с. 4. Хведчин Ю. Й. Брошурувально-палітурне устаткування. Ч. 2: Палітурне устаткування : Підручник. - Львів : УАД, 

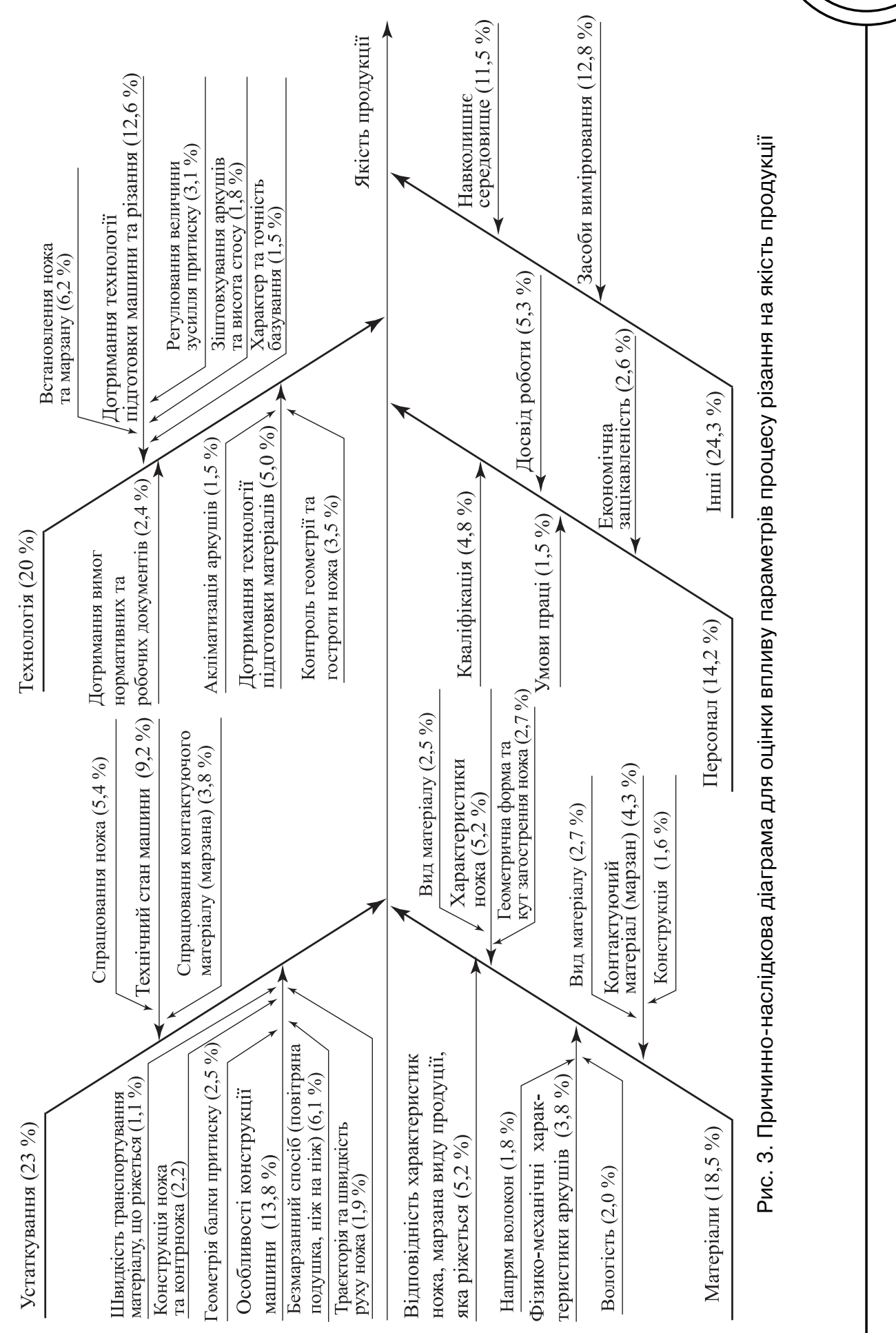
2007. - 392 с. 5. Топольницький П. В. Нові технології та пристрої для різання поліграфічних матеріалів та книжково-журнальних блоків : навч. посіб. / П. В. Топольницький, О. Б. Книш. - Львів : Афіша, 2003. - 88 с. 6. Топольницький П. В. Наукові основи безвистійного обрізування книжково-журнальних блоків : технологія і устаткування : Автореф. дис. на здобут. наук. ступ. док. техн. наук: 05.05.01 / Топольницький Петро Володимирович. - Львів, 2003. - 36 с. 7. Коломієць А. Б. Розробка технологічного процесу обрізування дискретно-дотичним способом книжково-журнальних блоків : дис. ... канд. техн. наук: 05.05.01 / Коломієць Андрій Борисович. - Львів, 2002. - 178 с. 8. Саати Т. Аналитическое планирование. Организация систем / Т. Саати, К. Кернс. - М. : Мир, 1991. - 284 с. 9. Евланов Л. Г. Экспертные оценки в управлении / Л. Г. Евланов, В. А. Кутузов. - М. : Экономика, 1978. - 133 с. 10. Мюллер И. Эвристические методы в инженерных разработках / И. Мюллер : [пер. с нем.]. - М. : Радио и связь, 1984. - 144 с. 11. Адлер Ю. П. Планирование эксперимента при порске оптимальних условий / Ю. П. Адлер, Е. В. Маркова, Ю. В. Грановский. - М. : Наука, 1976. - 154 с. 12. Федюкин В. Управление качеством процессов / В. Федюкин. - С-П. : ПитерМедиа, 2004. - 208 с. 13. Управління якістю та елементи системи якості : ДСТУ ISO 9004-4-98. -- [Чинний від 1998.04.03]. - К. : Держспоживстандарт України, 1998. - 25 с. - (Національні стандарти України). 14. Технологические инструкции. Брошюровочно-переплетные процессы. - М. : Книга. - 1982. - 440 с. 15. Справочник технологаполиграфиста. Ч. 6. Брошюровочно-переплетные процессы. - М. : Книга, 1985. - 296 с. 16. Воробьев Д. В. Технология брошюровочно-переплетных процессов / Д. В. Воробьев, А. И. Дубасов, Ю. М. Лебедев. - М. : Книга, 1989. - 392 c.

1. Shostachuk lu. O. Tekhnika i tekhnolohiia suchasnoho polihrafichnoho vyrobnytstva : navch. posib. / lu. O. Shostachuk. - K. : NTUU «KPI», 2009. 244 s. 2. Hvedchin Ju. I. Rezal'nye mashiny i kompleksy POLAR : uchebn. posob. / Ju. I. Hvedchin, Ju. A. Shostachuk, M. Ovchar. - K. : PKP «ST-Druk», 2004. - 204 s. 3. Khvedchyn Iu. I. Broshuruvalno-paliturne ustatkuvannia. Ch. 1. Broshuruvalne ustatkuvannia. Pidruchnyk / lu. I. Khvedchyn. - Lviv : TeRus, 1999. - 336 c. 4. Khvedchyn lu. I. Broshuruvalno-paliturne ustatkuvannia. Ch. 2: Paliturne ustatkuvannia : Pidruchnyk. - Lviv : UAD, 2007. - 392 s. 5. Topolnytskyi P. V. Novi tekhnolohii ta prystroi dlia rizannia polihrafichnykh materialiv ta knyzhkovo-zhurnalnykh blokiv : navch. posib. / P. V. Topolnytskyi, O. B. Knysh. - Lviv : Afisha, 2003. - 88 s. 6. Topolnytskyi P. V. Naukovi osnovy bezvystiinoho obrizuvannia knyzhkovo-zhurnalnykh blokiv : tekhnolohiia i ustatkuvannia : Avtoref. dys. na zdobut. nauk. stup. dok. tekhn. nauk: 05.05.01 / Topolnytskyi Petro Volodymyrovych. - Lviv, 2003. - 36 s. 7. Kolomiiets A. B. Rozrobka tekhnolohichnoho protsesu obrizuvannia dyskretno-dotychnym sposobom knyzhkovo-zhurnalnykh blokiv : dys. ... kand. tekhn. nauk: 05.05.01 / Kolomiiets Andrii Borysovych. - Lviv, 2002. - 178 s. 8. Saati T. Analiticheskoe planirovanie. Organizacija sistem / T. Saati, K. Kerns. - M. : Mir, 1991. - 284 s. 9. Evlanov L. G. Jekspertnye ocenki v upravlenii / L. G. Evlanov, V. A. Kutuzov. M. : Jekonomika, 1978. - 133 s. 10. Mjuller I. Jevristicheskie metody v inzhenernyh razrabotkah / I. Mjuller : [per. s nem.]. - M. : Radio i svjaz', 1984. 144 s. 11. Adler Ju. P. Planirovanie jeksperimenta pri porske optimal'nih uslovij / Ju. P. Adler, E. V. Markova, Ju. V. Granovskij. - M. : Nauka, 1976. - 154 s. 12. Fedjukin V. Upravlenie kachestvom processov / V. Fedjukin. - S-P. : PiterMedia, 2004. - 208 s. 13. Upravlinnia yakistiu ta elementy systemy 
yakosti : DSTU ISO 9004-4-98. -- [Chynnyi vid 1998.04.03]. - K. Derzhspozhyvstandart Ukrainy, 1998. - 25 s. - (Natsionalni standarty Ukrainy). 14. Tehnologicheskie instrukcii. Broshjurovochno-perepletnye processy. - M. : Kniga. - 1982. - 440 s. 15. Spravochnik tehnologapoligrafista. Ch. 6. Broshjurovochno-perepletnye processy. - M. : Kniga, 1985. - 296 s. 16. Vorob'ev D. V. Tehnologija broshjurovochno-perepletnyh processov / D. V. Vorob'ev, A. I. Dubasov, Ju. M. Lebedev. - M. : Kniga, 1989. $-392 \mathrm{~s}$.

Рецензент - О. В. Зоренко, к.т.н., доцент, НТУУ «КПІ»

Надійшла до редакції 26.03.13 